BIODIK: Jurnal IImiah Pendidikan Biologi
ISSN 2580-0922 (online), ISSN 2460-2612 (print)
Volume 6, Nomor 03, Tahun 2020, Hal. 242-255
Available online at:
https://online-journal.unja.ac.id/biodik

Research Article

\title{
Analisis, Uji Coba dan Rekontruksi Kegiatan Praktikum Melalui Lembar Kerja Peserta Didik Struktur dan Fungsi Sel
}

\section{(Analysis, Testing, Recontruction Of Practical Work Through Student Worksheet Structure And Cell Function)}

\author{
Anggi Angreani, Bambang Supriatno, Sri Anggraeni
}

Program Studi Pendidikan Biologi Universitas Pendidikan Indonesia

JI. Dr. Setiabudi No. 229, Bandung 40154, Indonesia

Corresponding Author: anggiangreani2@gmail.com

\begin{tabular}{|c|c|}
\hline Informasi Artikel & ABSTRACT \\
\hline $\begin{array}{l}\text { Submit: } 02-06-2020 \\
\text { Diterima: } 08-08-2020 \\
\text { Dipublikasikan: } 01-09-2020\end{array}$ & $\begin{array}{l}\text { This study contains an analysis of the Student Worksheets contained } \\
\text { in the high school textbook / used by teachers in schools, with the aim } \\
\text { of providing information, education or solutions to problems that have } \\
\text { arisen in practical activities. Practicum activities are an important part } \\
\text { of science education, so they are required to create more meaningful } \\
\text { practicum activities. In making practicum activities more meaningful } \\
\text { and achieving goals in accordance with Basic Competencies, one of } \\
\text { them is by reconstructing the Student Worksheet (LKPD). This study } \\
\text { is included in the descriptive qualitative, in which LKPD cell structure } \\
\text { and function are made as research subjects with a sample number of } \\
5 \text { LKPD that refers to the SBC and Curriculum 2013. The instrument } \\
\text { used in this research refers to: first, the form of analysis of laboratory } \\
\text { activities where problems are emerges namely in terms of conceptual } \\
\text { (practicum activities not in accordance with the curriculum), practical } \\
\text { (the object does not appear clearly because the procedure is less } \\
\text { precise) and knowledge (questions that do not construct knowledge). } \\
\text { Second, referring to the Vee Diagram developed from Novak \& } \\
\text { Gowin. The problems that arise include practical aspects which } \\
\text { include procedures / work steps, questions that lead to the results of } \\
\text { the practicum. therefore there is a need to reconstruct LKPD so LKPD } \\
\text { can be well understood and achievement in accordance with the } \\
\text { Basic Competition (KD). } \\
\text { Keywords: student worksheet, ANCOR Methods, structure and cell } \\
\text { function }\end{array}$ \\
\hline Penerbit & ABSTRAK \\
\hline $\begin{array}{l}\text { Program Studi Pendidikan } \\
\text { Biologi, Fakultas Keguruan } \\
\text { dan IImu Pendidikan, } \\
\text { Universitas Jambi }\end{array}$ & $\begin{array}{l}\text { Penelitian ini berisi tentang analisis terhadap Lembar Kerja Peserta } \\
\text { Didik yang terdapat pada buku SMA/yang digunakan oleh guru di } \\
\text { sekolah, dengan tujuan untuk memberikan informasi, edukasi atau } \\
\text { solusi terhadap masalah yang selama ini muncul dalam kegiatan } \\
\text { praktikum. Kegiatan praktikum merupakan salah satu bagian penting } \\
\text { dari pendidikan sains, sehingga diharuskan menciptakan kegiatan } \\
\text { praktikum yang lebih bermakna. Dalam menjadikan kegiatan } \\
\text { praktikum lebih bermakna dan tujuan pencapaian sesuai dengan } \\
\text { Kompetensi Dasar maka salah satu nya yaitu dengan melakukan } \\
\text { rekontruksi Lembar Kerja Peserta didik (LKPD). Penelitian ini } \\
\text { termasuk ke dalam deskriptif kualitatif, dimana LKPD struktur dan } \\
\text { fungsi sel di jadikan sebagai subjek penelitian dengan jumlah sampel } \\
5 \text { LKPD yang mengacu pada KTSP dan Kurikulum 2013. Instrumen } \\
\text { yang digunakan dalam penelitan ini mengacu pada: pertama, form }\end{array}$ \\
\hline
\end{tabular}


analisis kegiatan laboratorium dimana permasalahan yang muncu yaitu dari segi konseptual (kegiatan praktikum tidak sesuai dengan kurikulum), praktikal (objek tidak mucul secara jelas karena prosedurnya kurang tepat) dan pengetahuan (pertanyaan yang tidak mengkontruksi pada pengetahuan). Kedua, mengacu pada Diagram Vee yang dikembangkan dari Novak \& Gowin. Adapun masalah yang muncul diantaranya dari segi praktikal yang meliputi prosedur/langkah kerja, pertanyaan yang mengarah ke hasil praktikum. maka dari itu perlu adanya rekontruksi LKPD agar LKPD dapat di pahami dengan baik serta pencapaian sesuai dengan Kompetesi Dasar (KD).

Katakunci: Lembar Kerja Peserta didik, Metode ANCOR, Struktur dan Fungsi Sel

\section{PENDAHULUAN}

Proses pembelajaran biologi di sekolah pada umumnya menekankan pada pengalaman pembelajaran secara langsung. Menurut (Khoerunnisa et al., 2019) pembelajaran biologi menuntut peserta didik untuk belajar melalui pengalaman langsung dan pembelajaran kontekstual, sehingga peserta didik dapat mengekspresikan fenomena disekitar mereka. Salah satu cara agar peserta didik mendapatkan proses pengalaman belajar secara langsung yaitu melalui studi kegiatan praktikum. Praktikum adalah salah satu cara dalam merubah pembelajaran biologi yang minds on ke dalam pembelajaran yang hands on (Erwinsyah et al., 2016). Disamping itu, praktikum merupakan metode yang efektif dalam pengajaran sains. Hal tersebut dikarenakan dalam pembelajaran biologi dituntut untuk belajar dengan pengalaman langsung dan konstektual agar peserta didik mampu mengungkapkan fenomena yang ada disekitarnya (Aisya et al., 2016; Dewi et al., 2017). Menurut (Festile, 2017) kegiatan praktikum juga dilakukan oleh banyak pelajar, bahkan yang pasif. Kegiatan pratikum dilakukan untuk meningkatkan pemahaman siswa dan penunjang keterampilan proses sains (Harlis \& Budiarti, 2017). Hal tersebut didukung oleh pernyataan Okwoduba \& Okigbo (Koirala et al., 2019) bahwa praktikum juga disebut metode eksperimental yang digunakan peserta didik agar dapat belajar dengan mudah.

Kegiatan praktikum akan lebih terstruktur jika didukung dengan Lembar Kerja Peserta Didik (LKPD) yang baik karena LKPD yang baik akan menunjang terhadap hasil praktikum yang efektif atau sesuai tuntutan kurikulum. LKPD yang baik diantaranya terdapat langkah kerja dan pertanyaan yang mengarahkan pada kegiatan praktikum (Anggraeni \& Supriatno, 2020). LKPD juga merupakan suatu media pembelajaran yang baik sehingga perlu dibuat sesuai dengan karakteristik peserta didik, bahan serta fasilitas yang tersedia (Rosid et al., 2019). Akan tetapi, tidak jarang peserta didik memberikan respon negatif terhadap kegiatan praktikum sehingga kegiatan praktikum tersebut tidak sesuai dengan tujuan yang diharapkan. Hodson dalam (Millar, 2001) mengemukakan bahwa "seperti yang dipraktikkan di 
banyak sekolah (kerja praktek) adalah salah paham, bingung dan tidak produktif. bagi banyak peserta didik, apa yang terjadi di laboratorium berkontribusi sedikit pada pembelajaran sains mereka atau pembelajaran mereka tentang sains dan metodemetodenya juga tidak melibatkan mereka dalam melakukan kegiatan sains yang berarti. pada akar masalahnya adalah pada kegiatan praktikum yang tidak terpikirkan". Berdasarkan pernyataan tersebut dan fakta yang ada, hal ini berarti pendidik harus merancang suatu kegiatan prakikum yang menarik, sehingga peserta didik dapat belajar/melakukan praktikum secara produktif. Rancangan kegiatan praktikum yang menarik salah satunya dengan membuat rancangan Lembar Kerja Peserta Didik (LKPD) yang lebih efektif dan efisien. Disisi lain, penggunaan LKPD dapat memberikan kesempatan kepada peserta didik lebih banyak dalam belajar secara mandiri namun tetap berada dalam bimbingan guru, membaca uraian, dan memahami petunjuk di dalam lembaran kegiatan, menjawab pertanyaan-pertanyaan serta melaksanakan penyelesaian tugas (Hadinurdina \& Kurniati, 2019).

Praktikum merupakan bagian penting dari pendidikan sains. Dalam pelajaran sains, Abraham \& Millar dalam (Koirala et al., 2019) berusaha memperluas pengetahuan peserta didik tentang dunia alami dan mengembangkan pemahaman mereka tentang ide, teori dan model yang telah ditemukan oleh para ilmuwan. Adapun menurut (Sedumedi, 2017), mengatakan bahwa dengan kegiatan praktikum, pengetahuan dan keterampilan peserta didik dapat dinilai secara bersamaan. Praktikum dalam biologi merupakan salah satu hal yang harus dicapai berdasarkan Kompetensi Inti (KI) dan Kompetensi Dasar (KD). Misalnya pada materi "perbedaan struktur dan fungsi sel", yang mana KD pada kurikulum 2013 adalah 4.1 Melakukan pengamatan mikroskopis sel umbi lapis bawang merah dan sel epitel pipi, mengidentifikasi organel penyusunnya serta fungsinya. Sedangkan KD pada KTSP yaitu 1.2 Mengidentifikasi organel sel tumbuhan dan hewan. Analisis LKPD dilakukan karena terdapat sebagian LKPD tidak memenuhi Kompetensi Dasar yang telah ditetapkan sehingga kurang mengarahkan pada kegiatan praktikum. Adapun dari hasil analisis LKPD, peneliti mecoba melakukan rekontruksi LKPD agar kegiatan praktikum sesuai dengan tuntutan Kompetensi Dasar.

Berdasarkan KD tersebut, peserta didik dituntut untuk bisa mengamati bagian sel tumbuhan dan sel hewan serta mengidentifikasi organel sel dan fungsinya. Namun, tidak banyak ketercapaian KD dari praktikum tersebut, hal ini dibuktikan dengan beberapa Lembar Kerja Peserta didik yang digunakan di sekolah kurang efektif dan efisien. Lembar Kerja Peserta didik juga tak jarang kurang mengarahkan pada hasil praktikum.

Sehingga, untuk menjadikan praktikum lebih bermakna dan tujuan pencapaian sesuai dengan Kompetensi Dasar maka salah satu nya yaitu Lembar Kerja Peserta didik harus diperbaiki dengan cara "Rekontruksi Lembar Kerja Peserta didik". Disini juga akan di paparkan hasil rekontruksi LKPD khususnya pada praktikum perbedaan struktur dan fungsi sel berdasarkan hasil analisis LKPD sebelumnya tentang informasi, edukasi atau solusi terhadap masalah yang selama ini muncul dalam kegiatan praktikum. 


\section{METODE PENELITIAN}

Analisis LKPD termasuk ke dalam analisis deskriptif kualitatif, dimana LKPD struktur dan fungsi sel di jadikan sebagai subjek penelitian dengan jumlah sampel 5 LKPD yang mengacu pada KTSP dan Kurikulum 2013. Teknik sampling yang digunakan yaitu random sampling, dengan menggunakan metode ANCOR (Analisis, Coba, Rekontruksi). Dalam metode ANCOR, tahap pertama analisis di lakukan terhadap lima LKPD dari kurikulum yang berbeda yaitu kurikulum 2013 dan KTSP. Adapun tahapan analisis terhadap lima LKPD ini menggunakan form analisis kegiatan laboratorium dan tabel komponen diagram vee yang di kembangkan dari (Novak \& Gowin, 1984).

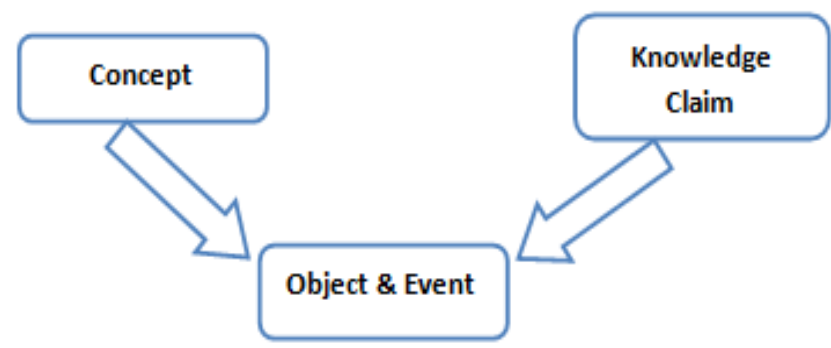

\section{Gambar 1 : Digram Vee}

Tahap ke dua, uji coba yang dilakukan dengan menggunakan langkah kerja dari salah satu LKPD yang belum di rekontruksi. Adapun langkah kerja yang dilakukan dalam mengamati sel tumbuhan yaitu dengan terlebih dahulu membersihkan object glass dan cover glass menggunakan alkohol, kemudian membuat preparat bawang merah dengan cara menyayat tipis sel bawang merah. Sayatan sel bawang merah di letakkan di atas object glass dan ditutup dengan cover glass kemudian di amati dengan mikroskop. Lakukan langkah kerja yang sama pada pengamatan sel hewan namun objek yang digunakan yaitu sel selaput pipi.

Tahap ke tiga, evaluasi dan perancangan rekontruksi. Adapun rekontruksi LKPD meliputi pada beberapa aspek seperti aspek konseptual, prosedural dan pengetahuan dengan berpedoman pada form analisis kegiatan laboratorium dan diagram vee.

\section{HASIL DAN PEMBAHASAN}

Analisis pertama yang dilakukan dalam penelitian ini adalah mengenai konten yang dipelajari. Analisis dilakukan berkaitan dengan Diagram Vee yang dikemukakan oleh Novak \& Gowin. Analisis meliputi fokus pertanyaan, metodologi, konsep dan prinsip, serta obyek. 


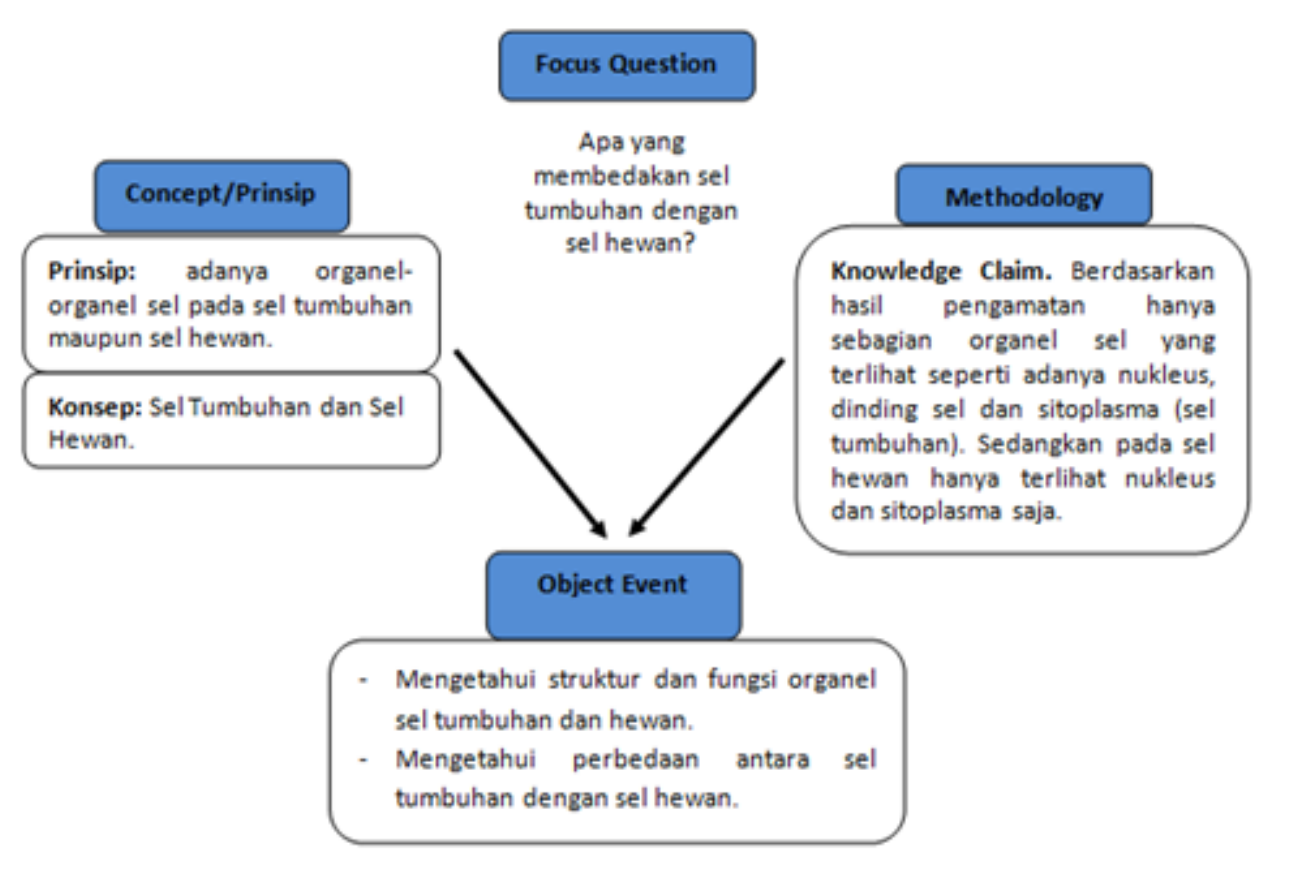

Gambar 2. Analisis diagram vee

Adapun hasil skor komponen pada Diagram Vee dapat di lihat pada Tabel 1. Diagram vee mencakup focus question, object event, teori/prinsip dan konsep, record/transformasi dan knowledge claim.

Tabel 1. Hasil Skor Komponen pada Diagram Vee

Komponen Perolehan Skor

Diagram Vee

LKPD 1 LKPD 2

LKPD 3

LKPD 4

4

\begin{tabular}{llllll}
\hline Focus question & 2 & 3 & 1 & 3 & 3 \\
\hline Object event & 3 & 1 & 2 & 3 & 3 \\
\hline Teori/prinsip/konsep & 2 & 1 & 0 & 2 & 0 \\
\hline Record/Transformasi & 3 & 3 & 4 & 4 & 4 \\
\hline Knowledge claim & 2 & 2 & 1 & 3 & 3 \\
\hline Jumlah Skor & $\mathbf{1 2}$ & $\mathbf{1 0}$ & $\mathbf{8}$ & $\mathbf{1 5}$ & $\mathbf{1 3}$
\end{tabular}

Berdasarkan analisis pada komponen pertama, terdapat 3 LKPD yang focus question nya teridentifikasi. Sedangkan LKPD 1 memiliki focus question yang teridentifikasi namun terdapat event yang salah atau tidak sesuai. Dan LKPD 3, focus question teridentifikasi tetapi tidak memandu perolehan konsep/event.

Komponen kedua, object/event pada 3 LKPD memiliki skor 3 dimana terdapat event utama yang teridentifikasi, konsisten dengan focus question dan dapat digunakan untuk merekam data. Sedangkan, pada LKPD 2 hanya event utama yang teridentifikasi, konsisten dengan focus question. LKPD 2, yang memiliki skor terendah yaitu event utama teridentifikasi akan tetapi tidak konsisten dengan focus question. 
Komponen ketiga, yaitu mengenai Teori/prinsip/konsep pada LKPD 2 dan LKPD 4 memiliki konsep yang teridentifikasi dan terdapat salah satu prinsip atau konsep dan teori yang relevan teridentifikasi. Sedangkan LKPD 2, konsep teridentifikasi tetapi tanpa prinsip dan teori. Sedangkan LKPD 3 dan LKPD 5 tidak ada konsep yang teridentifikasi. Kemudian, komponen ke empat mengenai record/transformasi, hampir semua teridentifikasi sesuai event dan focus question serta kegiatan laboratorium sesuai dengan level peserta didik.

Terakhir, komponen ke lima yaitu tentang knowledge claim, pada LKPD 4 dan 5 meliputi konsep yang dapat digunakan untuk mengenerelasikan dan konsisten dengan record dan transformasi. LKPD 1 dan 2, knowledge claim meliputi konsep yang dapat digunakan untuk mengenerasikan tetapi tidak konsisten dengan record dan transformasi. Sedangkan, LKPD 3 knowledge claim nya tidak berhubungan dengan konsep, prinsip dan teori. Adapun analisis kedua pada LKPD yaitu menggunakan form analisis kegiatan laboratorium yang berkaitan dengan kesesuaian struktur dari LKPD yang digunakan oleh peserta didik. Analisis ini dilakukan terhadap lima LKPD yang kemudian dijadikan sebagai pembanding serta disesuaikan dengan parameter yang digunakan. Adapun bentuk analisis LKPD dapat di lihat pada Tabel 2.

Tabel 2. Form Analisis Kegiatan Laboratorium

Analisis Konseptual

\begin{tabular}{|c|c|c|c|c|c|c|}
\hline No & Parameter & LKPD 1 & LKPD 2 & LKPD 3 & LKPD 4 & $\begin{array}{l}\text { LKPD } \\
5\end{array}$ \\
\hline 1 & $\begin{array}{l}\text { Kesesuaian Konten dengan Kompetensi } \\
\text { Dasar }\end{array}$ & - & - & $\sqrt{ }$ & $\sqrt{1}$ & - \\
\hline 2 & Kesesuaian Kompetensi dengan KD & - & - & $\sqrt{ }$ & - & $\sqrt{ }$ \\
\hline 3 & Kesesuaian Judul dengan kegiatan & - & - & $\sqrt{ }$ & $\sqrt{ }$ & \\
\hline 4 & $\begin{array}{l}\text { Kesesuaian Tujuan dengan Langkah } \\
\text { Kerja }\end{array}$ & - & $\sqrt{ }$ & - & $\sqrt{ }$ & $\sqrt{ }$ \\
\hline 5 & $\begin{array}{l}\text { Kesesuaian } \\
\text { Kesesuaian Kegiatan dengan Tingkat } \\
\text { Kognitif Peserta didik }\end{array}$ & $\sqrt{ }$ & - & - & $\sqrt{ }$ & $\sqrt{ }$ \\
\hline \multicolumn{7}{|c|}{ Analisis Praktikal } \\
\hline 1 & $\begin{array}{l}\text { Apakah alat-alatnya sesuai dengan } \\
\text { standar/tersedia sekolah }\end{array}$ & $\sqrt{ }$ & $\sqrt{ }$ & $\sqrt{ }$ & $\sqrt{ }$ & $\sqrt{ }$ \\
\hline 2 & $\begin{array}{l}\text { Apakah bahan praktikum dapat } \\
\text { disediakan dengan mudah }\end{array}$ & $\sqrt{ }$ & - & - & $\sqrt{ }$ & $\sqrt{ }$ \\
\hline 3 & Apakah langkah-langkahnya terstruktur & - & - & $\sqrt{ }$ & $\sqrt{ }$ & $\sqrt{ }$ \\
\hline 4 & $\begin{array}{l}\text { Apakah setiap langkah dapat dieksekusi } \\
\text { tanpa kesulitan }\end{array}$ & - & - & - & - & - \\
\hline 5 & Apakah objek/fenomenanya muncul & $\sqrt{ }$ & $\sqrt{ }$ & $\sqrt{ }$ & $\sqrt{ }$ & $\sqrt{ }$ \\
\hline 6 & Apakah objek/fenomena mudah diamati & $\sqrt{ }$ & $\sqrt{ }$ & $\sqrt{ }$ & $\sqrt{ }$ & $\sqrt{ }$ \\
\hline 7 & Apakah ada perekaman data & $\sqrt{ }$ & $\sqrt{ }$ & $\sqrt{ }$ & $\sqrt{ }$ & $\sqrt{ }$ \\
\hline 8 & $\begin{array}{l}\text { Bagaimana bentuk perekaman } \\
\text { objek/fenomena }\end{array}$ & \multicolumn{5}{|c|}{$\begin{array}{l}\text { Hasil pengamatan pada mikroskop di foto kemudian } \\
\text { foto dari mikroskop di gambar pada tabel } \\
\text { pengamatan yang dibuat }\end{array}$} \\
\hline 9 & Apakah objek fenomena relevan dengan & $\sqrt{ }$ & $\sqrt{ }$ & $\sqrt{ }$ & $\sqrt{ }$ & $\sqrt{ }$ \\
\hline
\end{tabular}


judul/tujuan

10 Berapa lama waktu yang digunakan untuk melaksanakan kegiatan praktikum

11 Adakah petunjuk safety lab?

\begin{tabular}{|c|c|c|c|c|c|c|}
\hline \multicolumn{7}{|c|}{ Analisis Pengetahuan } \\
\hline 1 & $\begin{array}{l}\text { Apakah pertanyaan semua dapat } \\
\text { dijawab tanpa praktikum? }\end{array}$ & & - & $\sqrt{ }$ & $\sqrt{ }$ & $\sqrt{ }$ \\
\hline 2 & $\begin{array}{l}\text { Apakah menanyakan karakter fakta } \\
\text { yang muncul }\end{array}$ & $\sqrt{ }$ & $\sqrt{ }$ & $\sqrt{ }$ & $\sqrt{ }$ & - \\
\hline 3 & $\begin{array}{l}\text { Apakah fakta digunakan untuk } \\
\text { mengkontruksi konsep? }\end{array}$ & $\sqrt{ }$ & $\sqrt{ }$ & - & $\sqrt{ }$ & - \\
\hline 4 & Apakah ada proses interpretasi data? & $\sqrt{ }$ & $\sqrt{ }$ & $\sqrt{ }$ & - & - \\
\hline 5 & $\begin{array}{l}\text { Apakah ada pertanyan } \\
\text { kemunculan suatu prinsip? }\end{array}$ & - & $\sqrt{ }$ & - & - & - \\
\hline 6 & Apakah ada pertanyaan terkait analisis? & - & - & - & $\sqrt{ }$ & $\sqrt{ }$ \\
\hline 7 & $\begin{array}{l}\text { Apakah penarikan kesimpulan } \\
\text { berdasarkan data yang direkam? }\end{array}$ & $\sqrt{ }$ & - & - & $\sqrt{ }$ & - \\
\hline
\end{tabular}

\section{Uji Coba Praktikum}

Tahap selanjutnya, setalah analisis terhadap diameter atau konten LKPD, dilakukan uji coba praktikum terhadap salah satu LKPD yang bertujuan untuk melihat kekurangan atau ketidak terbacaan pada LKPD tersebut. Adapun tahapan uji coba praktikum pada salah satu LKPD dapat di lihat pada Tabel 3.

Tabel 3. Tahapan Uji Coba Praktikum

\section{Pelaksanaan Konten LKPD / Dokumentasi}

Alat dan bahan praktikum yang akan digunakan dipersiapkan terlebih dahulu.

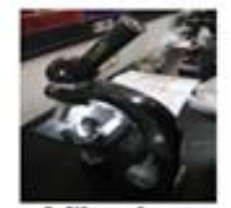

Mikrosicop

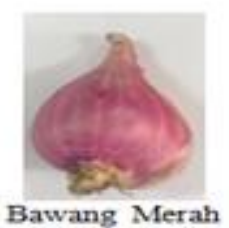

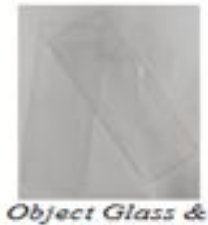

Object Glass \&

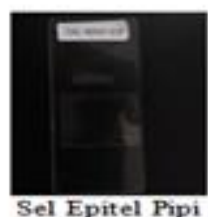

Sel Epitel Pipi

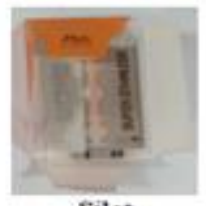

Silet

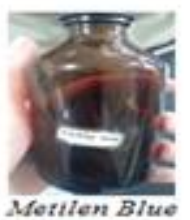

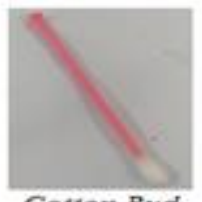

Cotton Bud

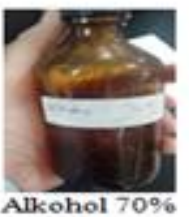

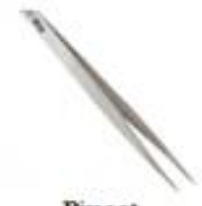

Pinset

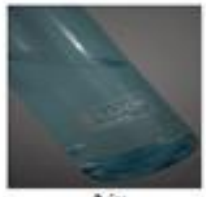

Gambar 3. Alat dan Bahan

(Sumber: Dokumentasi Pribadi, 2020)

\section{Pelaksanaan Konten LKPD / Dokumentasi}

Langkah Pengerjaan Uji Coba Praktikum:

1. Sayat tipis lapisan bawang merah.

2. Sayatan tipis sel bawang merah diletakkan di atas object glass dan ditetesi metilen blue, kemudian ditutup dengan cover glass.

3. Lapisan lendir diambil dari pipi bagian dalam, kemudian diletakkan goresan lendir pipi di atas object glass dan ditetesi metilen blue, kemudian ditutup dengan cover glass.

4. Preparat sayatan sel bawang merah dan epitel pipi di amati melalui mikroskop 


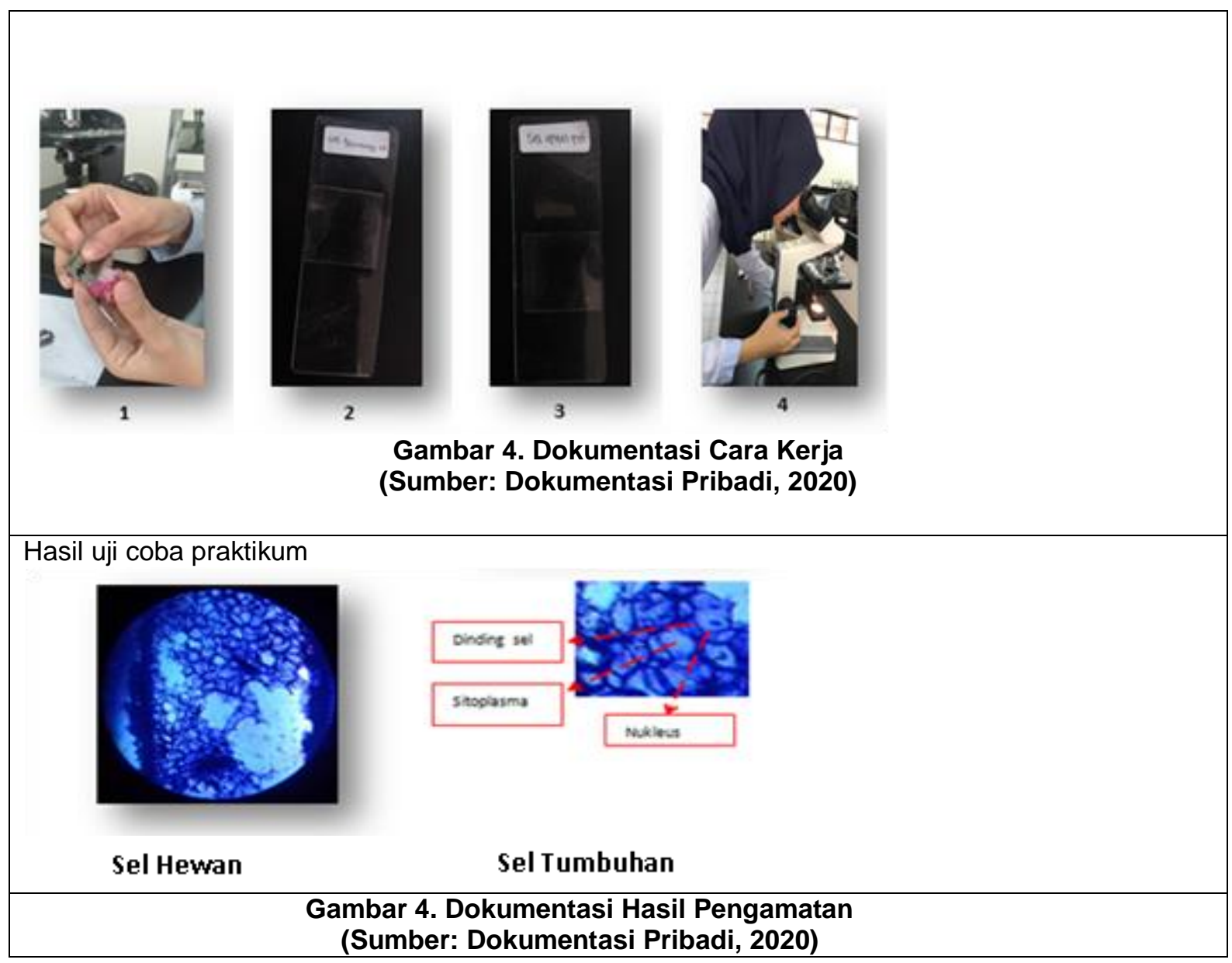

Gambar 4 menunjukkan hasil pada sel hewan dan sel tumbuhan. Perbedaan tersebut nampak jelas, akan tetapi hasil yang terlihat di mikroskop hanya dapat di amati beberapa organel sel nya saja. Pada sel tumbuhan, organel sel yang teramati hanya bagian dinding sel, sitoplasma dan nukleus. Adapun dinding sel tumbuhan merupakan matriks ekstraseluler yang menyelubungi tiap sel tumbuhan yang berfungsi melindungi sel tumbuhan, mempertahankan wujudnya, dan mencegah pengisapan air yang berlebihan. Sedangkan, nukleus berperan sebagai pengendali sel eukariotik (Reece et al., 2012).

Melalui praktikum seperti ini, peserta didik memiliki pengalaman dalam melihat bentuk sel secara langsung melalui mikroskop yang ia amati. Abrahams dan Millar dalam (Festile, 2017) juga mengatakan bahwa kegiatan praktikum dapat melibatkan kegiatan dimana peserta didik melihat benda serta bahan secara nyata. Secara garis besar, adapun hasil rekontruksi LKPD pada struktur dan fungsi sel, dapat di lihat pada Gambar 5 dan Gambar 6. 


\section{Hasil Rekontruksi LKPD}

\section{LEMBAR KERJA PESERTA DIDIK Apakah Struktur Fungsi Sel Hewan Dan Sel Tumbuhan Sama?}

\section{Kelompok \\ Nama Anggota :}

\section{A. Tujuan Pembelajaran}

1. Menyajikan hasil pengamatan mikroskopik struktur sel hewan dan sel tumbuhan sebagai unit terkecil kehidupan

2. Mengidentifikasi organel penyusun sel hewan dan sel tumbuhan (yang bisa di amati)

3. Mengidentifikasi perbedaan sel hewan dan sel tumbuhan

\section{B. Dasar Teori}

Sel merupakan suatu unit kecil yang bibatasi oleh membran, yang akan membentuk suatu organisme dan berfungsi dalam menjalankan fungsi kehidupan. Setiap organisme tersusun dari salah satu jenis sel yang secara struktural berbeda, yaitu sel prokariotik (tidak memiliki membran inti) atau sel eukariotik (memiliki membran inti). Contoh organisme yang memiliki sel prokariotik yaitu bakteri dan arkea. Sedangkan, yang memiliki sel eukariotik yaitu protista, jamur, tumbuhan dan hewan.

Sel hewan dan sel tumbuhan meskipun sama-sama termasuk ke dalam sel eukariotik, akan tetapi ke duanya memiliki struktur dan organel sel yang sedikit berbeda. Organel sel yang dimiliki sel hewan diantaranya yaitu nukleus, sentriol, lisosom, mitokondria, retikulum endoplasma, ribosom. Sedangkan, Organel sel yang dimiliki sel tumbuhan diantaranya nukleus, dinding sel, ribosom, retikulum endoplasma, plastida, vakuola sentral.

\section{Alat dan Bahan}

\begin{tabular}{ll} 
Alat & Jumlah \\
\hline Mikroskop & 1 \\
Object Glass & 2 \\
Cover Glass & 2 \\
Silet & Minimal 1 \\
Pinset & Minimal 1 \\
Tusuk gigi/cotton bud & Secukupnya \\
Pipet tetes & 2 \\
Label & 2 \\
Tissue & Secukupnya \\
\hline Bahan & Jumlah \\
\hline Sel epitel pipi & secukupnya \\
Sel bawang merah & secukupnya \\
Alkohol 70\% & secukupnya \\
Metilen Blue & $1-2$ tetes
\end{tabular}




\section{Cara Kerja}

\section{Pengamatan Sel Tumbuhan}

1. Bersihkan object glass dan cover glass dengan alkohol $70 \%$.

2. Bersihkan lapisan epidermis bawang yaitu siung dari bawang merah menggunakan silet atau pinset.

3. Buatlah preparat dari umbi bawang merah dengan cara mengambil sayatan tipis yang ada di tiap lapis umbi bawang merah secara melintang. Lakukan dengan hati-hati!

4. Letakkan sayatan tipis tersebut di atas object glass (dibantu dengan menggunakan pinset), tetesi objek dengan metilen blue, kemudian tutuplah dengan cover glass.

5. Amatilah dengan mikroskop.

6. Gambarlah hasil pengamatanmu di tabel hasil pengamatan!.

\section{Pengamatan Sel Hewan}

1. Bersihkan object glass dan cover glass dengan alkohol $70 \%$.

2. Goreslah dengan perlahan bagian pipi dengan tusuk gigi/cotton bud sehingga memperoleh lapisan lendir. Lakukan dengan hati-hati!

3. Letakkan hasil goresan tersebut di atas object glass, tetesi objek dengan metilen blue, kemudian tutuplah dengan cover glass.

4. Amatilah dengan mikroskop.

5. Gambarlah hasil pengamatanmu di tabel hasil pengamatan!.

E. Tabel Hasil Pengamatan

\begin{tabular}{|l|l|}
\hline Gambar Sel Hewan & Gambar Sel Tumbuhan \\
\hline & \\
& \\
\hline
\end{tabular}

\section{F. Pertanyaan}

1. Bagian organel sel apa saja yang dapat diamati pada sel hewan dan sel tumbuhan?

2. Apakah sel yang kamu amati termasuk ke dalam golongan eukariot? Jika Ya, kemukakan alasannya!

3. Berdasarkan hasil pengamatan, adakah perbedaan antara sel hewan dan sel tumbuhan?

4. Bagaimana cara untuk membedakan antara sel hewan dan sel tumbuhan?

5. Mengapa organel sentriol, dinding sel dan kloropil hanya di miliki oleh sel tumbuhan atau sel hewan saja? Hubungkan dengan peran hewan/tumbuhan dalam kehidupan! 


\section{G. Kesimpulan}

Analisis pertama Lembar Kerja Peserta didik (LKPD) dilakukan dengan menganalisis struktur LKPD dengan didasarkan pada parameter yang merujuk pada form analisis kegiatan laboratorium berdasarkan kajian Supriatno, B. Adapun analisis yang dilakukan meliputi analisis konseptual, praktikal dan rekontruksi pengetahuan. Berdasarkan hasil analisis yang dilakukan terhadap lima LKPD, untuk analisis konseptual terdapat 1 LKPD (yaitu LKPD 4) yang kegiatan praktikumnya sesuai dengan tuntutan kurikulum, meskipun masih ada ketidak sesuaian kompetensi dengan KD, seperti hanya melakukan pengamatan saja tanpa melakukan identifikasi. Sedangkan dalam kegiatan praktikum harus sesuai dengan tuntutan Kompetensi Dasar karena peserta didik akan dapat merumuskan masalah, menyusun kerangka berpikir, menguji hipotesis dan menarik kesimpulan (Sumarmin \& Roza, 2019).

Kemudian, berdasarkan hasil analisis praktikal, semua LKPD dapat menghadirkan objek, namun hanya LKPD 3, 4 dan 5 yang prosedur/ langkahlangkahnya tepat dan jelas jika dibandingkan dengan dua LKPD lainnya. LKPD 1 dan 3 memiliki prosedur yang kurang dipahami dengan mudah seperti dalam satu nomor, terdapat beberapa langkah kerja yang harus di lakukan, dan sebaiknya setiap step yang berbeda di tuliskan pada nomor selanjutnya. Kemudian langkah-langkah untuk mengamati sel hewan dengan sel tumbuhan di tuliskan secara terpisah. Hal ini bertujuan agar peserta didik dapat memahami prosedur dengan baik sehingga menghasilkan penafsiran yang baik. Menurut (Wahidah et al., 2015), meskipun prosedur praktikum disajikan secara rinci, terdapat diantaranya tidak terstruktur dan perintah kerja yang membingungkan sehingga menimbulkan penafsiran ganda.

Alat dan bahan yang digunakan pun sudah memenuhi standar (tersedia di sekolah/mudah di dapatkan), kecuali di salah satu LKPD terdapat bahan yang belum sesuai standar. Penyajian informasi mengenai alat dan bahan yang digunakan tidak lengkap akan membuat peserta didik tidak mempersiapkan alat dan bahan secara lengkap sehingga pelaksanaan praktikum pun terganggu (Sumarmin \& Roza, 2019). Adapun dalam kegiatan praktikum hendaknya peserta didik mendapatkan kesempatan untuk secara aktif memperoleh data atas objek yang di observasi dan atau manipulasi sehingga memungkinkan adanya proses kontruksi pengetahuan berbasis informasi faktual (Supriatno, 2018).

Namun, hasil kontruksi pengetahuan tidak semua pertanyaan yang terdapat di LKPD mengacu pada fakta. Meskipun terdapat pertanyaan yang mengacu pada fakta, namun pertanyaan fakta tersebut tidak semuanya digunakan untuk mengontruksi konsep seperti pada LKPD 3 dan 5. Menurut (Novak \& Gowin, 1984), untuk mendapatkan belajar yang berarti, individu harus memilih dalam menghubungkan pengetahuan baru dengan konsep yang sesuai dan proporsi yang telah diketahuinya. Sedangkan, pada LKPD 4, pertanyaan fakta digunakan untuk 
mengontruksi konsep, seperti menyebutkan organel sel yang dimiliki oleh sel hewan dan sel tumbuhan. kemudian, pertanyaan-pertanyaan lain mengenai fakta dan konsep juga tidak memunculkan keterkaitan suatu prinsip sehingga bagian interprestasi kurang memadai. Maka dari itu, pertanyaan yang baik dalam merekontruksi fakta menjadi pengetahuan harus saling berkaitan satu sama lainnya. Hal tersebut dikarenakan, ketika melakukan kerja laboratorium peserta didik menemukan fakta, prinsip dan fenomena dengan cara observasi untuk memantapkan pengetahuan dan membentuk pengetahuan yang baru (Supriatno, 2013).

Mengaju pada penelitian (Arafah et al., 2012) telah melakukan rekontruksi LKPD, dimana bagian pertanyaan pada LKPD tersebut dapat memancing kemampuan berpikir kritis dan kreatif peserta didik. Peserta didik di tuntut untuk mengidentifikasi masalah, menilai /mengambil keputusan terhadap suatu masalah, menjelaskan dan menafsirkan fakta, menganalisis masalah, mengemukakan pendapat, mengevaluasi pendapat serta menyimpulkan masalah berdasarkan fakta.

Setelah analisis dilaksanakan, selanjutnya masuk ke tahap uji coba dengan tujuan untuk melihat apakah terdapat kendala atau tidak dalam langkah pengerjaan nya. Dari hasil uji coba tersebut, terdapat beberapa kendala yang dirasa sulit atau kurang efektif untuk dilaksanakan, seperti ketika membuat sayatan yang setipis mungkin agar objek dapat terlihat jelas dan sel tampak tidak menumpuk. Dari kendala tersebut maka diperlukan rekontruksi dengan tujuan untuk memperbaiki kesalahan agar hasil semakin efektif dan menuntun peserta didik menjadi mandiri. (Arafah et al., 2012) juga mengemukakan bahwa LKPD berisi langkah-langkah kegiatan dalam praktikum agar menuntut peserta didik untuk mandiri.

Disamping itu, konten yang dipelajari peserta didik dikaitkan dengan analisis Diagram Vee, yang membahas tentang focus question, object \& event, teori/ konsep/prinsip, Record / Transformasi, dan knowledge claim. Berdasarkan hasil skor komponen pada Diagram Vee, skor tertinggi terdapat pada komponen record/trasformasi dikarenakan semua LKS menginstruksikan untuk mengintrepretasi data ke dalam gambar yang di sajikan pada tabel. Sedangkan, skor terendah terdapat pada komponen teori/prinsip/konsep, hal ini berarti analisis tersebut di dapatkan bahwa dalam kegiatan praktikum harus menekankan pada teori/konsep/prinsip berdasarkan fakta yang di dapat.Praktikum tentang pengamatan sel hewan maupun sel tumbuhan penting untuk dilaksanakan, karena untuk meningkatkan tingkat kognitif serta memberi bekal untuk melaksanakan praktikum selanjutnya (tentang jaringan).

\section{KESIMPULAN}

Berdasarkan hasil analisis LKPD, terdapat permasalahan yang muncul seperti kegiatan praktikum yang kurang sesuai dengan tuntutan $K D$, kurang menghadirkan objek secara jelas, pertanyaan kurang mengarahkan berdasarkan fakta dan kurang adanya keterkaitan kemunculan suatu prinsi/konsep. Sehingga, diperoleh bahwa rekontruksi LKPD memang perlu dilakukan untuk menunjang kegiatan praktikum 
yang lebih baik, serta dapat membelajarkan peserta didik dalam menjelaskan sesuai dengan fakta dan data yang ia peroleh. Adapun, analisis LKPD melalui kegiatan praktikum dengan metode ANCOR merupakan strategi efektif dalam mengembangkan desain kegiatan praktikum dan dapat di jadikan sebagai acuan dalam pembuatan rekontruksi LKPD selanjutnya

\section{DAFTAR PUSTAKA}

Aisya, N. S. M., Saefudin, S., Supriatno, B., \& Anggraeni, S. (2016). Penerapan Diagram Vee dalam Model Pembelajaran Inquiry Lab dan Group Investigation untuk Meningkatkan Kemampuan Literasi Kuantitatif Siswa Kelas VII pada Materi Pencemaran Lingkungan. Proceeding Biology Education Conference: Biology, Science, Enviromental, and Learning, 13(1), 112-117.

Anggraeni, S., \& Supriatno, B. (2020). Analisis dan Rekonstruksi Lembar Kerja Peserta Didik Indra Pengecap Berbasis Diagram Vee. BIODIK, 6(2), 200-213. https://doi.org/https://doi.org/10.22437/bio.v6i2.9441

Arafah, S. F., Priyono, B., \& Ridlo, S. (2012). Pengembangan LKS berbasis berpikir kritis pada materi animalia. Journal of Biology Education, 1(1).

Dewi, R., Budiarti, R. S., \& Aina, M. (2017). Pengembangan lembar kegiatan peserta didik (Ikpd) bermuatan pendidikan karakter dengan model pembelajaran guided inquiry pada materi bakteri bagi siswa kelas $\mathrm{x}$ sekolah menengah atas. BIODIK, 3(1), 17-26. https://doi.org/https://doi.org/10.22437/bio.v3i1.4878

Erwinsyah, R., Riandi, R., \& Nurjhani, M. (2016). Relevansi praktikum dan perkuliahan teori pada mata kuliah genetika. Proceeding Biology Education Conference: Biology, Science, Enviromental, and Learning, 13(1), 546-553. https://doi.org/https://jurnal.uns.ac.id/prosbi/article/view/5826

Festile, R. M. (2017). The influence of Practical Work in the teaching and learning of acids, bases and neutrals in Natural Sciences. University of the Western Cape. https://doi.org/http://etd.uwc.ac.za/handle/11394/5921

Hadinurdina, H., \& Kurniati, A. (2019). Pengembangan Lembar Kerja Siswa (LKS) Berbasis Problem Solving untuk Memfasilitasi Kemampuan Pemecahan Masalah Matematis Siswa Madrasah Tsanawiyah. JURING (Journal for Research in Mathematics Learning), 1(3), 189-198.

https://doi.org/http://dx.doi.org/10.24014/juring.v1i3.5398

Harlis, H., \& Budiarti, R. S. (2017). Pengembangan bahan ajar praktikum dan instrumen penilaian berbasis keterampilan proses sains pada mata kuliah mikologi program studi pendidikan biologi universitas jambi. BIODIK, 3(2), 102112. https://doi.org/https://doi.org/10.22437/bio.v3i2.5501

Khoerunnisa, R. S., Supriatno, B., \& Nuraeni, E. (2019). Implementation of DPDPE learning strategies using photosynthetic kits to enhance students' quantitative literacy. Journal of Physics: Conference Series, 1, 1-5. https://doi.org/10.1088/1742-6596/1521/4/042003

Koirala, K. P., Pak, B., Seifert, L., Brandt, S., van Rijt, D., Schacher, B., Uhse, A., Obreja, K., Parvini, P., \& Gerhardt-Szep, S. (2019). Effectiveness of Practical Work on Students' Achievement in Science at Secondary Level in Gorkha District Nepal. Journal of Advances in Education Research, 4(4), 139-161. https://doi.org/Vol. 4, No. 4, November 2019 https://dx.doi.org/10.22606/jaer.2019.44001 Millar, R. (2001). Teaching and learning science through practical work. Prosiding 
Outline of Talk given at Nordlab-DK Seminar. Copenhagen.

Novak, J. D., \& Gowin, D. B. (1984). Learning how to learn. cambridge University press.

Reece, J. B., Taylor, M. R., Simon, E. J., \& Dickey, J. L. (2012). Campbell biology: concepts \& connections. Benjamin Cummings San Francisco, CA.

Rosid, A., Sunarya, Y., \& Arifin, M. (2019). Teacher Training Scaffolding Type to Improve Teacher's Ability in Development of Guided Inquiry Practical Worksheet. KnE Social Sciences, 178-188. https://doi.org/10.18502/kss.v3i10.3900

Sedumedi, T. D. T. (2017). Practical work activities as a method of assessing learning in chemistry teaching. Eurasia Journal of Mathematics, Science and Technology Education, 13(6), 1765-1784. https://doi.org/https://doi.org/10.12973/eurasia.2017.00697a

Sumarmin, R., \& Roza, R. K. (2019). Pengembangan Penuntun Praktikum Biologi Berbasis Pendekatan Saintifik untuk MTS/SMP Kelas VII Semester II. JURNAL EKSAKTA PENDIDIKAN (JEP), 3(2), 152-158. https://doi.org/https://doi.org/10.24036/jep/vol3-iss2/334

Supriatno, B. (2013). Pengembangan program perkuliahan pengembangan praktikum biologi sekolah berbasis ANCORB untuk mengembangkan kemampuan merancang dan mengembangkan desain kegiatan laboratorium. Universitas Pendidikan Indonesia.

Supriatno, B. (2018). Praktikum untuk Membangun Kompetensi. Proceeding Biology Education Conference: Biology, Science, Enviromental, and Learning, 15(1), 118.

Wahidah, N. S., Supriatno, B., \& Kusumastuti, M. N. (2015). Analisis Struktur dan Kemunculan Tingkat Kognitif pada Desain Kegiatan Laboratorium Materi Fotosintesis. Assimilation: Indonesian Journal of Biology Education, 1(2), 70-76. https://doi.org/https://doi.org/10.17509/aijbe.v1i2.13050 